\title{
HEPATITIS C VIRUS GENOTYPES IN A NORTHEASTERN AREA OF BRAZIL
}

\author{
LUCIANO K. SILVA, RAIMUNDO PARANÁ, SÉRGIO P. SOUZA, FRANÇOISE BERBY, ALAN KAY, CHRISTIAN TREPÓ, \\ NELMA SANTANA, HELMA COTRIM, LUIZ G. LYRA, AND MITERMAYER G. REIS \\ Laboratório de Patologia e Biologia Molecular, Centro de Pesquisas Gonçalo Moniz, Fundação Oswaldo Cruz, Salvador, Bahia, \\ Brazil; Institut National de la Santé et de la Recherche Médicale Unité 271, Lyon, France; Gastroenterologia-Hepatologia, \\ Universidade Federal da Bahia, Salvador, Bahia, Brazil
}

\begin{abstract}
We used a reverse transcription-polymerase chain reaction (RT-PCR) to obtain the genotypes of circulating hepatitis $\mathrm{C}$ virus (HCV) in patients from a Gastro-Hepatology Unit in the city of Salvador (Bahia State) in northeastern Brazil. Viral RNA was detected in $83(65.4 \%)$ of 127 anti-HCV seropositive serum samples. Positivity was significantly associated with alterations in levels of aspartate aminotransferase and alanine aminotransferase $(P$ $<0.05$ ). Genotyping of HCV was performed by RT-PCR using genotype-specific primers from the core region: $24.1 \%$ were infected with subtype $1 \mathrm{a}, 38.6 \%$ with $1 \mathrm{~b}, 3.6 \%$ with $2,21.7 \%$ with $3 \mathrm{a}$, and $12.0 \%$ with a mixed genotype. There was no difference in genotype distribution when compared with results from other Brazilian locations. Surprisingly, the high frequency of genotype 3 in Brazilian samples continues to be different from that reported around the world and warrants further investigation.
\end{abstract}

Hepatitis $\mathrm{C}$ virus (HCV), a recently discovered virus of low viremia and immunogenicity, is unique among viruses infecting human beings in that the detection of viral RNA remains the most sensitive and reliable means of confirming infection. In addition, variations in nucleotide sequences are used to determine genotypes. ${ }^{1-7}$ Since the discovery of $\mathrm{HCV}$ by Choo and others, ${ }^{8}$ more than 80 genotypes have been identified. The sequences of the subgenomic regions of these genotypes differ by more than $20 \% .^{7}$ The classification of HCV genotypes by Simmonds and others ${ }^{7}$ groups $\mathrm{HCV}$ isolates by a phylogenetic anal$y$ sis of sequence variation in part of a 222-basepair (bp) of a region coding for the nonstructural protein NS5b. They found 2 different tiers of sequence variation within this region and classified HCV into 6 types designated by Arabic numbers $(1,2,3$, etc.) and further divided into subtypes designated by letters (a, b, c, etc.). The distribution of HCV genotypes has been found to vary geographically. ${ }^{9}$ Genotypes 1,2 , and 3 and their subtypes are distributed worldwide. In contrast, genotype 4 appears to be a pan-African type (the principal genotype in Zaire and Egypt), and genotype 5 has been found to be the principal genotype in South Africa. ${ }^{10,11}$ Genotype 6 and its variants have been found mainly in Asia. ${ }^{1,9,12}$ In Brazil, recent studies performed in the southeastern (States of São Paulo and Rio de Janeiro) and southern (State of Rio Grande do Sul) regions demonstrated the presence of $3 \mathrm{HCV}$ genotypes $\left(1,2\right.$, and 3). ${ }^{13-16}$ Studies suggest that the clinical features of liver disease depend on HCV genotypes. ${ }^{17-20}$ For instance, an association between certain genotypes and disease severity, liver cirrhosis, and primary liver cancer has been reported. ${ }^{19}$ It is also noteworthy that the success of interferon treatment seems to be type or subtype related. ${ }^{21}$ These observations make the identification of infecting HCV genotypes from different geographic regions of great interest.

The primary objective of the present study was to detect and determine the genotypes of circulating $\mathrm{HCV}$ isolates in northeastern Brazil. The relationship between HCV RNA positivity and alterations in levels of aspartate aminotransferase (AST) or alanine aminotransferase (ALT) was determined.

\section{MATERIALS AND METHODS}

Samples. Sera were collected from 127 repeatedly antiHCV seropositive subjects (age range $=13-75$ years; male: female ratio $=98: 29$ ) who consecutively attended the Gastro-Hepatology Unit of the University Hospital of Bahia between May and September 1997. Serology was performed using a third-generation enzyme immune assay (EIA) (HCV EIA III; Abbott Laboratories, North Chicago, IL). None of the subjects were drug addicts. All samples were aliquoted within $2 \mathrm{hr}$ and stored immediately at $-70^{\circ} \mathrm{C}$ until use. Aliquots were not thawed more than once prior to analysis. A complete follow-up of AST and ALT levels (Dimension RxL; Dade Behring, Newark, DE) over a 6-month period was obtained for 65 subjects. The AST and ALT levels were routinely determined at 3 points and were found to be within normal ranges (12-37 U/L for AST and 30-65 U/L for ALT) or altered. This project was approved by the Institution Ethical Committee and informed consent was obtained from each subject.

Extraction of HCV RNA and cDNA synthesis. Two hundred microliters of serum were used for HCV RNA extraction by the guanidinium isothiocyanate-phenol-chloroform method $^{22}$ and then precipitated with ethanol and dried. ${ }^{23}$ The HCV RNA was immediately doubly transcribed into cDNA using the antisense primers NC4 (ACT CGC AAG CAC CCT ATC AGG CAG TAC) from the 5' non-coded region $\left(5^{\prime} \mathrm{NCR}\right)$ and 186 NTER (ATA GAG AAA GAG CAA CCG GG) from the core region.

Detection of HCV RNA. A combined reverse transcription-polymerase chain reaction (RT-PCR) was used in 2 different experiments to amplify cDNA from each sample and from positive and negative controls. For standardization of the HCV RNA detection system, 35 samples were tested blindly. These were 12 positive controls with known concentration of $\mathrm{HCV}$ (as determined in the Quantiplex HCV RNA 2.0 assay; Chiron Corp., Emeryville, CA) and 23 negative controls. Negative controls consisted of samples from normal individuals and from patients infected by other viral agents, such as hepatitis A virus and hepatitis B virus. All negative controls were found to be repeatedly anti-HCV negative and HCV RNA negative. The PCR was carried out 


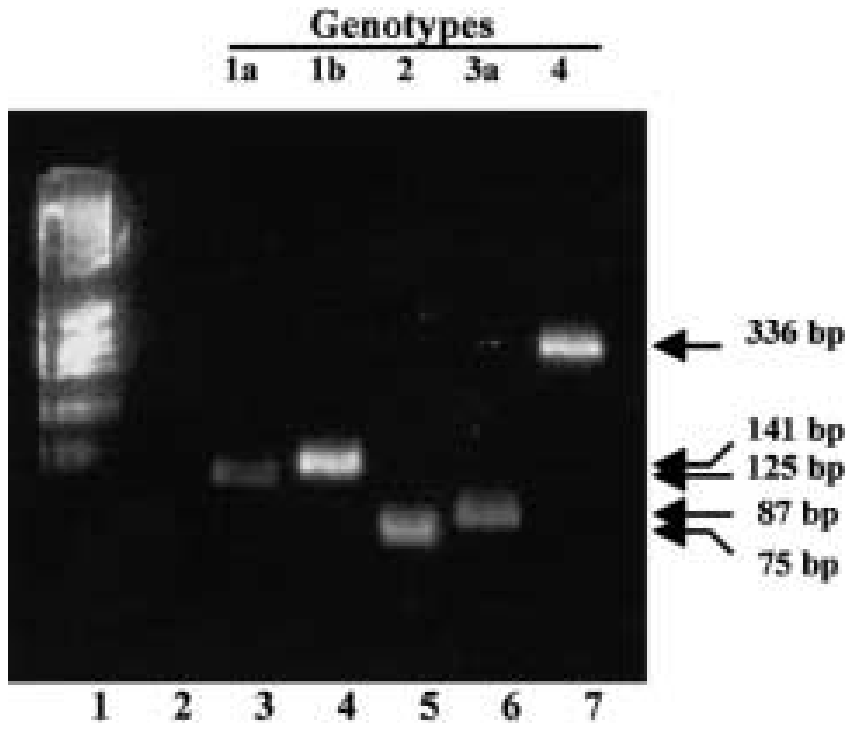

FIGURE 1. Electrophoresis of hepatitis $\mathrm{C}$ virus polymerase chain reaction (PCR) products (pattern of reaction in the second-round genotyping PCR). The specificity was checked by the ability of the primers to amplify DNA with predicted length, using cDNAs for genotypes $1 \mathrm{a}, 1 \mathrm{~b}, 2,3 \mathrm{a}$, and 4 , which had been determined by mixed primers located in the core region, as described by Lerat and others. ${ }^{25}$ Lane 1, molecular weight marker; lane 2, blank control; lanes $3-7$, genotype-specific products. $b p=$ basepairs.

with the sense primer NC3 (CCT GTG AGG AAC TAC TGT CTT CAC GCA) and the antisense primer NC4 for 45 cycles $\left(94^{\circ} \mathrm{C}\right.$ for $45 \mathrm{sec}, 64^{\circ} \mathrm{C}$ for $45 \mathrm{sec}$, and $72^{\circ} \mathrm{C}$ for 1 min). ${ }^{24}$ Positivity was initially established by electrophoresis on a $3 \%$ agarose gel and staining the gel with ethidium bromide. The size of the RT-PCR product was $268 \mathrm{bp}$.

Southern blotting. The identification of the amplified product as coded for $\mathrm{HCV}$-derived $\mathrm{HCV}$-cDNA was confirmed by Southern blotting with probe A89 (CCA TAG TGG TCT GCG GAA CCG GTG AGT ACA) labeled with biotin or ${ }^{32} \mathrm{P}$. Samples that were negative by staining with ethidium bromide, but positive in the Southern blot were retested.

Genotyping of HCV. This was accomplished by means of a nested PCR assay that uses primers located in the core region and amplifies genotype-specific sequences. ${ }^{25}$ Briefly, a first PCR $(5 \mu \mathrm{l}$ of RNA, total $=50 \mu \mathrm{l})$ was carried out with the sense primer 256 (CGC GCG ACT AGG AAG ACT TC), and the antisense primer 186 NTER for 40 cycles $\left(94^{\circ} \mathrm{C}\right.$ for $1 \mathrm{~min}, 55^{\circ} \mathrm{C}$ for $1.5 \mathrm{~min}$, and $72^{\circ} \mathrm{C}$ for $2 \mathrm{~min}$ ). These oligonucleotides were used as generic primers capable of amplifying cDNA of all HCV genotypes because their sequences seem to be well conserved in ubiquitous isolates. The amplified product $(1 \mu \mathrm{l})$ was subjected to a second PCR (total $=50 \mu \mathrm{l})$ using combinations of 10 primers specific for 4 different HCV genotypes: 1 ( $a$ and b), 2, 3 (a), and 4. Four sense primers, 104 (AGG AAG ACT TCC GAG CGG TC), 104 IIa (AGG AAG ACT TCG GAG CGG TC), 104 IIIa (CGT AAA ACT TCT GAA CGG TC), and 104 IVa (CGA AAG ACT TCG GAG CGG TC); and 6 antisense primers, 132 Nbis (GCA GCC CTC ATT GCC ATA), 133 Nbis (GCC ATC CTG CCC ACC CCA TG), 134 Nbis1 (ACT TGC CAG TGG AGC GCC G), 134 Nbis2 (ATT TGC
TABLE 1

Association between HCV RNA positivity and AST/ALT levels*

\begin{tabular}{|c|c|c|c|}
\hline $\begin{array}{c}\text { Aminotransferase levels } \\
\text { during a } \\
\text { follow-up for } 6 \text { months }\end{array}$ & $\begin{array}{l}\text { Number of } \\
\text { subjects (\%) }\end{array}$ & $\begin{array}{l}\text { HCV RNA } \\
\text { positivity (\%) }\end{array}$ & $P \dagger$ \\
\hline \multicolumn{4}{|l|}{ AST } \\
\hline Persistently normal & $12(18.5)$ & 41.7 & 0.001 \\
\hline Altered & $53(81.5)$ & 88.7 & \\
\hline \multicolumn{4}{|l|}{ ALT } \\
\hline Persistently normal & $14(21.5)$ & 57.1 & 0.03 \\
\hline Altered & $51(78.5)$ & 86.3 & \\
\hline
\end{tabular}

CAG TGG AGC GCC G), 339 Nbis (GCT GAG CCC AGG ACC GGC CT), and 465 (TCC CGT CCT CCA CAG CCC TG), were used. Thirty-five cycles were performed at $94^{\circ} \mathrm{C}$ for $1 \mathrm{~min}, 63^{\circ} \mathrm{C}$ for $1 \mathrm{~min}$, and $72^{\circ} \mathrm{C}$ for $1.5 \mathrm{~min}$. Primers combinations, expected size of products, and corresponding detected genotypes/subtypes were as follows: 104/132Nbis, 125 bp, 1a; 104/133Nbis, 141 bp, 1b; 1041IIa/134Nbisl-2, $75 \mathrm{bp}, 2$; 104IIIa/339Nbis, $87 \mathrm{bp}, 3 \mathrm{a}$; and 104IVa/465 and $336 \mathrm{bp}, 4 \mathrm{a}$. The products from second-round genotyping PCR were analyzed by electrophoresis on a $3 \%$ agarose gel and stained with ethidium bromide. Figure 1 shows the band pattern consistently produced by the PCR with the genotypespecific primers.

\section{RESULTS}

Hepatitis C virus RNA was detected in 83 (65.4\%) of 127 samples examined. All results were confirmed with biotin and ${ }^{32} \mathrm{P}$-labeled probes. None of the samples were PCR-positive, Southern blot-negative by either of the different hybridization methods, although detection with radioactive probes was at least 10 times more sensitive than with biotin probes. There was no statistically significant association between HCV RNA positivity and either mildly altered (fluctuating) or persistently elevated levels of transaminases. However, HCV RNA positivity was significantly associated with abnormal AST and ALT levels in patients during a 6month follow-up $(P=0.001$ and $P=0.03$, respectively) (Table 1).

All HCV RNA-positive samples were typeable as 1a, 1b, 2 , 3a, or mixed genotype (Table 2). No statistically significant correlation of HCV types with age or gender was found.

\section{DISCUSSION}

The detection of HCV infection in this study was based on amplification by RT-PCR of fragments from the $5^{\prime} \mathrm{NCR}$,

TABLE 2

Prevalence of hepatitis $\mathrm{C}$ virus genotypes in patients from a referral Gastro-Hepatology Unit in Bahia State in northeast Brazil

\begin{tabular}{|c|c|c|c|c|c|c|}
\hline \multicolumn{6}{|c|}{ No. $(\%)$ of isolates of the genotype } & \multirow[b]{3}{*}{ All } \\
\hline \multicolumn{2}{|c|}{ Type 1} & \multirow{2}{*}{$\begin{array}{c}\text { Type } 2 \\
2 \mathrm{a} / 2 \mathrm{~b}\end{array}$} & \multirow{2}{*}{$\begin{array}{c}\text { Type } 3 \\
3 \mathrm{a}\end{array}$} & \multirow[b]{2}{*}{ Type 4} & \multirow[b]{2}{*}{ Mixed* } & \\
\hline $1 \mathrm{a}$ & $1 \mathrm{~b}$ & & & & & \\
\hline $20(24.1)$ & $32(38.6)$ & $3(3.6)$ & $18(21.7)$ & $0(0.0)$ & $10(12.0)$ & $83(100.0)$ \\
\hline
\end{tabular}


the most conserved region in the HCV genome. ${ }^{24,26-28} \mathrm{Hep}-$ atitis C virus RNA was detected in $65.4 \%$ (83 of 127) of the samples and was shown to be significantly associated with AST and ALT levels. These data confirm that active HCV infection develops in a large proportion of anti-HCV-positive subjects and provide further evidence to support its association with changes in AST or ALT levels during the course of infection. ${ }^{29,30}$ However, HCV RNA was also detected in some subjects with AST and ALT levels that were persistently normal. This constitutes a well-known virologic/biochemical dissociation in chronic HCV infection.

Despite optimization of the RT-PCR to detect HCV RNA in serum (the lower limit of detection was approximately 0.2 $\times 10^{-6} \mathrm{HCV}$ RNA molecules/ml), 34.6\% (44 of 127) of the serum samples of the anti-HCV-positive individuals were continuously HCV RNA negative. Fifteen subjects had a complete follow-up for serum AST and ALT levels. Seven $(46.7 \%)$ had no biochemical abnormalities, while 8 had fluctuations in the levels of these transaminases. However, positivity for HCV RNA cannot be excluded by the methodology used herein. Indeed, recent studies have suggested that detection of HCV RNA in serum or plasma is underestimated, and the use of other specimens, including whole blood and liver tissue, has been recommended to increase the sensitivity of detection of HCV RNA. ${ }^{31,32}$ On the other hand, one cannot exclude the possibility of false-positive anti-HCV EIA results during screening. In addition, some subjects may represent cases of complete resolution of infection. Alternatively, the possibility of a latent infection, with very low viral replication, has been suggested by the disappearance in acute $\mathrm{HCV}$ infection of $\mathrm{HCV}$ RNA from serum, with subsequent reappearance. ${ }^{33}$

For HCV genotyping, an assay ${ }^{25}$ adapted from the original technique of Okamoto and others, ${ }^{5,34}$ which uses type-specific primers located in the core region for amplification of genotype-specific sequences, was used. This is the first time that an RT-PCR was used to detect $\mathrm{HCV}$ infection in the State of Bahia, Brazil. There was no difference in the genotype distribution compared with studies in other Brazilian locations. ${ }^{13-16}$ Various HCV types, particularly 1 and 3, were equally distributed by age and gender. This apparent homogeneity may represent a peculiarity of the studied population. However, larger series of patients should be studied to ascertain this possibility.

Genotype 1 was the most prevalent $(62.7 \%)$, followed by genotype $3(21.7 \%)$, with few genotype 2 isolates $(3.6 \%)$. Subtypes $1 \mathrm{~b}, 1 \mathrm{a}$, and $3 \mathrm{a}$ were predominant, with prevalences of $38.6 \%, 24.1 \%$, and $21.7 \%$, respectively, whereas subtype $2 \mathrm{a} / 2 \mathrm{~b}$ was rarely found $(3.6 \%)$ in the studied population. The high prevalence of genotypes 1 and 3 in Brazil is different from what is observed in the United States, Europe, and Japan, where genotypes 1 and 2 are the most frequent. ${ }^{35}$ In particular, genotype 3 has a high prevalence among intravenous drug users in Europe. ${ }^{2,36}$ In the population studied herein there were no drug addicts; however, genotype 3 occurred in a high frequency. The absence of genotype 4 in our samples indicates that it is absent or rarely present in our population. Since many people in Bahia are of African descent, this may suggest that either $\mathrm{HCV}$ infection is relatively recent or that genotype 4 infections have been supplanted by infections by other genotypes. Ten samples had a mixed pattern, 9 of subtypes $1 \mathrm{a} / 3 \mathrm{a}$ and 1 of $1 \mathrm{a} / 1 \mathrm{~b}$. Mutations in the core region or co-infection may explain these findings.

Direct sequencing analysis will be used to enable the identification of possible novel subtypes in future studies. Finally, the demonstration that HCV genotype distribution in Brazil is relatively homogeneous should facilitate Public Health surveillance policies. Further investigation is needed to understand the epidemiologic relevance of genotype 3 of HCV, unrelated to drug addiction, described in this paper.

Acknowledgments: We thank the subjects for compliance in participating in this study, the staff from collaborative institutions that constitute the Group of Study and Research in Hepatitis, SalvadorBA, Brazil (GEPH-BA) for efficient assistance during the field surveys, and Dr. Lain P. Carvalho for careful reading and review of the manuscript.

Financial support: This work was partially supported by research grants from the Conselho Nacional de Pesquisa e Desenvolvimento Tecnológico Program (CNPq) (Individual Processes \#350.052/956NV and \#360.850/95-2NV) between November 1995 and November 1997; Fundação Coordenação de Aperfeiçoamento de Pessoal de Nível Superior between December 1997 and February 1998; Programa Nacional de Excelência (Promex 4196086200); and the Scientific Collaboration Program between Fundação Oswaldo Cruz (Brazil) and the Institut National de la Santé et de la Recherche Médicale (Lyon, France).

Authors' addresses: Luciano K. Silva, Sérgio P. de Souza, and Mitermayer G. Reis, Centro de Pesquisas Gonçalo Moniz-FIOCRUZ, R. Waldemar Falcão, 121-Brotas, 40295-001 Salvador, Bahia, Brazil. Raimundo Paraná, Nelma Santana, Helma Cotrim, and Luiz G. Lyra, Laboratório Gastroenterologia e Hepatologia, $6^{\circ}$ Andar do Hospital Universitário Professor Edgard Santos, R. Augusto Viana, s/n-Canela, 40110-060 Salvador, Bahia, Brazil. Françoise Berby, Alan Kay, and Christian Trepó, Institut National de la Santé et de la Recherche Médicale Unité 271, Cours Albert Thomas, 151, Lyon France.

Reprint requests: Mitermayer G. Reis, Centro de Pesquisas Gonçalo Moniz-FIOCRUZ, R. Waldemar Falcão, 121-Brotas, 40295-001 Salvador, Bahia, Brazil.

\section{REFERENCES}

1. Bukh J, Purcell RH, Miller RH, 1993. At least 12 genotypes of hepatitis $\mathrm{C}$ virus predicted by sequence analysis of the putative El gene of isolates collected worldwide. Proc Natl Acad Sci USA 90: 8234-8238.

2. Chan SW, McOmish F, Holmes EC, Dow B, Peutherer JF, Follett E, Yap PL, Simmonds P, 1992. Analysis of a new hepatitis C virus type and its phylogenetic relationship to existing variants. J Gen Virol 73: 1131-1141.

3. Enomoto N, Takada A, Nakao T, Date T, 1990. There are two major types of hepatitis $\mathrm{C}$ virus in Japan. Biochem Biophys Res Commun 170: 1021-1025.

4. Mori S, Kato N, Yagyu A, Tanaka T, Ikeda Y, Petchclai B, Chiewsilp P, Kurimura T, Shimotohno K, 1992. A new type of hepatitis $\mathrm{C}$ virus in patients in Thailand. Biochem Biophys Res Commun 183: 334-342.

5. Okamoto H, Sugiyama Y, Okada S, Kurai K, Akahane Y, Sugai Y, Tanaka T, Sato K, Tsuda F, Miyakawa Y, Mayumi M, 1992. Typing hepatitis $\mathrm{C}$ virus by polymerase chain reaction with type-specific primers: application to clinical surveys and tracing infectious sources. J Gen Virol 73: 673-679.

6. Okamoto H, Kobata S, Tokita H, Inoue T, Woodfield GD, Holland PV, Al Knawy BA, Uzunalimoglu O, Miyakawa Y, Mayumi M, 1996. A second-generation method of genotyping hepatitis $\mathrm{C}$ virus by the polymerase chain reaction with sense and antisense primers deduced from the core gene. $J$ Virol Methods 57: 31-45. 
7. Simmonds P, Holmes EC, Cha TA, Chan SW, McOmish F, Irvine B, Beall E, Yap PL, Kolberg J, Urdea MS, 1993. Classification of hepatitis $\mathrm{C}$ virus into six major genotypes and a series of subtypes by phylogenetic analysis of the NS-5 region. J Gen Virol 74: 2391-2399.

8. Choo QL, Kuo G, Weiner AJ, Overby LR, Bradley DW, Houghton $\mathrm{M}, 1989$. Isolation of cDNA clone derived from a blood borne non-A, non-B, viral hepatitis genome. Science 244: 359-362.

9. McOmish F, Yap PL, Dow BC, Follett EA, Seed C, Keller AJ, Cobain TJ, Krusius T, Kolho E, Naukkarinen R, Lin C, Leong S, Medgyesi GA, Hejas M, Kiyokawa H, Fukuda K, Cuypers T, Saeed AA, Al-Rasheed AM, Lin M, Simmonds P, 1994. Geographical distribution of hepatitis $\mathrm{C}$ virus genotypes in blood donors: an international collaborative survey. $J$ Clin Microbiol 32: 884-892.

10. Dusheiko GM, Schmilovitz-Weiss H, Brown D, McOmish F, Yap P-L, Sherlock S, McIntyre N, Simmonds P, 1994. Hepatitis $\mathrm{C}$ virus genotypes: an investigation of typespecific differences in geographic origin and disease. Hepatology 19: 1318.

11. Ohno T, Mizokami M, Tibbs CJ, Ohba K, Suzuki K, Wu RR, Nouri Aria KT, Williams R, 1994. New genotype of hepatitis C virus in South Africa. J Med Virol 42: 409-413.

12. Mellor J, Walsh EA, Prescott LE, Jarvis LM, Davidson F, Yap PL, Simmonds P, 1996. Survey of type 6 group variants of hepatitis $\mathrm{C}$ virus in Southeast Asia by using a core-based genotyping assay. J Clin Microbiol 34: 417-423.

13. Bassit L, Ribero-dos-Santos G, da Silva LC, Takeio K, Villaca P, David-Neto E, Chamone D, Saéz-Alquezár A, 1999. Genotype distributions of hepatitis C virus in Sao Paulo, Brazil: rare subtype found (letter). Hepatology 29: 994-995.

14. Holland PV, Barrera JM, Ercilla MG, Yoshida CF, Wang Y, de Olim GA, Betlach B, Kuramoto K, Okamoto K, 1996. Genotyping hepatitis $\mathrm{C}$ virus isolates from Spain, Brazil, China, and Macau by a simplified PCR method. J Clin Microbiol 34: 2372-2378.

15. Krug LP, Lunge VR, Ikuta N, Fonseca AS, Cheinquer H, Ozaki LS, Barros SG, 1996. Hepatitis C virus genotypes in southern Brazil. Braz J Med Biol Res 29: 1629-1632.

16. Stuyver L, Rossau R, Wyseur A, Duhamel M, Vanderborght B, Van Heuverswyn H, Maertens G, 1993. Typing of hepatitis C virus isolates and characterization of new subtypes using a line probe assay. J Gen Virol 74: 1093-1102.

17. Guen B, Squadrito G, Nalpas B, Bertherlot P, Pol S, Bréchot C, 1997. Hepatitis C virus genome complexity correlates with response to interferon therapy: a study in French patients with chronic hepatitis C. Hepatology 25: 1250-1254.

18. Silini E, Bono F, Cividini A, Cerino A, Bruno S, Rossi S, Belloni G, Brugnetti B, Civardi E, Salvaneschi L, Mondelli MU, 1995. Differential distribution of hepatitis C virus genotypes in patients with and without liver function abnormalities. Hepatology 21: 285-290.

19. Zein NN, Rakela J, Krawitt EL, Reddy KR, Tominaga T, Persing DH, 1996. Hepatitis C virus genotypes in the United States: epidemiology, pathogenicity, and response to interferon ther- apy. Collaborative Study Group (see comments). Ann Intern Med 125: 634-639.

20. Pozzato G, Moretti M, Franzin F, Croce LS, Tiribelli C, Masayu T, Kaneko S, Unoura M, Kobayashi K, 1991. Severity of liver disease with different hepatitis C virus clones. Lancet 338: 509.

21. Kohara M, Tanaka T, Tsukiyama Kohara K, Tanaka S, Mizokami M, Lau JY, Hattori N, 1995. Hepatitis C virus genotypes 1 and 2 respond to interferon-alpha with different virologic kinetics. J Infect Dis 172: 934-938.

22. Chomczynski P, Sacchi N, 1987. Single-step method of RNA isolation by acid guanidinium thiocyanate-phenol-chloroform extration. Anal Biochem 162: 156-159.

23. Sambrook J, Fritsch EF, Maniatis T, 1989. Molecular Cloning: A Laboratory Manual. Cold Spring Harbor, NY: Cold Spring Harbor Laboratory Press.

24. Li JS, Tong SP, Vitvitski L, Trepo C, 1995. Single-step nested polymerase chain reaction for detection of different genotypes of hepatitis C virus. J Med Virol 45: 151-155.

25. Lerat H, Rumin S, Habersetzer S, Berby F, Trabaud MA, Trepo $\mathrm{C}, 1998$. In vivo tropism of hepatitis $\mathrm{C}$ virus genomic sequences in hematopoietic cells: influence of viral load, viral genotype, and cell phenotype. Blood 91: 3841-3849.

26. Bukh J, Purcell RH, Miller RH, 1992. Sequence analysis of the 5 ' noncoding region of hepatitis C virus. Proc Natl Acad Sci USA 89: 4942-4946.

27. Kaneko S, Unoura M, Kobayashi K, Kuno K, Murakami S, Hattori N, 1990. Detection of serum hepatitis C virus RNA. Lancet 335: 976.

28. Kato N, Yokosuka O, Omata M, Hosoda K, Ohto M, 1990. Detection of hepatitis $\mathrm{C}$ virus ribonucleic acid in the serum by amplification with polymerase chain reaction. J Clin Invest 86: $1764-1767$.

29. Lok ASF, Cheung R, Chan R, Liu V, 1992. Hepatitis C viremia in patients with hepatitis $\mathrm{C}$ virus infection. Hepatology 15: 1007-1012.

30. Hoofnagle JH, 1997. Hepatitis C: the clinical spectrum of disease. Hepatology 26: 15s-20s.

31. Schmidt WN, Wu P, Han JQ, Perino MJ, LaBrecque DR, Stapleton YIF, 1997. Distribution of hepatitis C virus (HCV) RNA in whole blood and blood cell fractions: plasma HCV RNA analysis underestimates circulating virus load. $J$ Infect Dis 176: 20-26.

32. Schmidt WN, Wu P, Cedema J, Mitros FA, LaBrecque DR, Stapleton JT, 1997. Surreptitious hepatitis C virus (HCV) infection detected in the majority of patients with cryptogenic chronic hepatitis and negative HCV antibody tests. J Infect Dis 176: 27-33.

33. Parana R, Trepo C, Vitvitski L, Lyra L, 1999. Hepatitis C: does a healing state exist? Am J Gastroenterol 99: 862-863.

34. Okamoto H, Tokita H, Sakarnoto M, Horikita M, Kojima M, Iizuka H, Mishiro S, 1993. Characterization of the genomic sequence of type V (or 3a) hepatitis C virus isolates and PCR primers for specific detection. J Gen Virol 74: 2385-2390.

35. Brechot C, 1996. Hepatitis C virus: molecular biology and genetic variability. Dig Dis Sci 41: 6s-21s.

36. Bukh J, Miller RH, Purcell RH, 1995. Genetic heterogeneity of hepatitis C virus: quasispecies and genotypes. Semin Liver Dis 15: 41-63. 